\title{
CONTINUOUS AND HIGH-RESOLUTION ICE-CORE ANALYSIS \\ (Abstract)
}

by

C.U. Hammer

(Geophysical Institute, Department of Glaciology, University of Copenhagen, Haraldsgade 6, DK - 2200 Copenhagen N, Denmark)

\section{ABSTRACT}

The aim of this paper is to evaluate and exemplify the potential of continuous and high-resolution ice-core analysis in atmospheric-climatic research.

At present only a few ice-core components of current interest can be measured continuously with high resolution along the cores. In this paper, the techniques of in-situ or "in the laboratory" continuous high-resolution measurement of solid-liquid electrical conductivity, $\mathrm{pH}$, dust and anions will be presented and discussed. In particular, results from individual precipitation samples, seasonal changes, rare events, and the comparison of results from various Antarctic and Greenland ice cores will be discussed.

\section{CHEMICAL COMPOSITION OF INSOLUBLE PARTICLES IN AN ICE CAP ON STOR $\phi$ YA, SVALBARD \\ (Abstract)}

by

Jost Heintzenberg and Margareta Källström

(Department of Meteorology, University of Stockholm, S-10691 Stockholm, Sweden)

Hans-Christen Hansson

(Department of Nuclear Physics, Lund Institute of Technology, S-22362 Lund, Sweden)

and

Stig Jonsson

(Department of Physical Geography, University of Stockholm, S-10691 Stockholm, Sweden)

\begin{abstract}
During the Ymer-80 expedition, a $6 \mathrm{~m}$ long ice core was taken on the low-lying ice cap Storøyjøkulen, Svalbard. Core samples of about $10 \mathrm{ml}$ were filtered on $0.1 \mu \mathrm{m}$ pore-size Nuclepore filters, for analysis with a soot photometer and by means of particle-induced X-ray emission, which yielded elemental carbon and about 15 metals in the insoluble microparticles. The concentrations
\end{abstract}

were comparable to Arctic snow data from other locations. Multivariate statistical analysis of the chemical results indicates two major factors affecting microparticle composition: crustal and anthropogenic. A regular seasonal concentration pattern was found which is consistent with the c. $40 \mathrm{~cm}$ annual accumulation deduced from mass-balance studies on the ice cap. 